\title{
Revisiting the Nature of Phosphorus Pools in Chilean Volcanic Soils as a Basis for Arbuscular Mycorrhizal Management in Plant P Acquisition
}

\author{
Fernando Borie ${ }^{1,2,3}$. Paula Aguilera ${ }^{1,2} \cdot$ Claudia Castillo $^{2,3} \cdot$ Alexander Valentine $^{4} \cdot$ Alex Seguel $^{1,2}$. \\ José Miguel Barea ${ }^{5}$. Pablo Cornejo ${ }^{1,2}$
}

Received: 20 April 2018 / Accepted: 11 March 2019 / Published online: 3 April 2019

(C) Sociedad Chilena de la Ciencia del Suelo 2019

\begin{abstract}
This review covers the nature, characteristics, and reactivity of soil organic matter (SOM) in volcanic soils and the phosphorus $(\mathrm{P})$ accumulation mainly via the formation of stable complexes with organic and inorganic constituents to form P-containing macromolecules derived from both pedogenesis and fertilization. With the time, $\mathrm{P}$ accumulates as organic and inorganic compounds with differing lability, but the bulk appears to be recalcitrant. Chilean volcanic soils follow this same trend, subsequently having detrimental characteristics for plant growth, like the highly humified SOM and high P-sorption capacity. In addition, certain Chilean volcanic soils have high acidity, concomitant with a high exchangeable Al. As a result of the continuous application of $\mathrm{P}$ fertilizers, together with a low $\mathrm{P}$ efficiency of plant root acquisition, a "P reservoir" has built up, giving rise to the so-called residual $\mathrm{P}$. This residual $\mathrm{P}$ consists of the inorganic and organic $\mathrm{P}$, as macromolecular structures representing the cumulative average of several decades worth of agronomic $\mathrm{P}$ usage. Root modifications are an essential biological intervention to deal with this $\mathrm{P}$ accumulation. The general root modifications that are required to mobilize the residual $\mathrm{P}$ are discussed in the context of biochemical modifications (root exudations) and the symbiotic alterations by arbuscular mycorrhizal (AM) fungi. For a more efficient utilization of this accumulated $\mathrm{P}$, however, it is essential to investigate the chemical nature and lability of these $\mathrm{P}$ forms in order to determine their capacity for plant acquisition and utilization. In this context, attention is focused on $\mathrm{P}$ fractionation and on some ${ }^{31} \mathrm{P}-\mathrm{NMR}$ analysis of residual P constituents in Andisols. The major root trait evaluated and discussed here is the AM association, which is able to be extensively modified by management practices. Finally, some potential practices to avoid the excessive application of $\mathrm{P}$ fertilizers in volcanic soils by using technologies of $\mathrm{P}$ recycling, management of AM fungal populations, or agricultural management for mobilizing the accumulated residual $\mathrm{P}$ are outlined.
\end{abstract}

Keywords Andisols $\cdot$ Arbuscular mycorrhizal fungi $\cdot$ Inorganic $\mathrm{P} \cdot$ Organic $\mathrm{P}$

\section{Introduction}

According to Soil Survey Staff (2014), the volcanic ashderived soils, known as Andisols, cover approximately

In memoriam Dr. José Miguel Barea Navarro.

\section{Pablo Cornejo}

pablo.cornejo@ufrontera.cl

1 Centro de Investigación en Micorrizas y Sustentabilidad Agroambiental, CIMYSA. Departamento de Ciencias Químicas y Recursos Naturales, Universidad de La Frontera, P.O. Box 54-D, Temuco, Chile

2 Scientific and Technological Bioresource Nucleus, BIOREN-UFRO, Universidad de La Frontera, P.O. Box 54-D, Temuco, Chile
124 Mha worldwide, corresponding to $0.84 \%$ of the total land surface. For management purposes, Andisols are divided in two groups based on the dominance of allophone in the surface or lack thereof: (i) 'allophanic Andisols', dominated by

3 Facultad de Recursos Naturales, Universidad Católica de Temuco, Campus San Juan Pablo II, Rudecindo Ortega, 02950 Temuco, Chile

4 Botany and Zoology Department, Faculty of Science, University of Stellenbosch, Stellenbosch, South Africa

5 Departamento de Microbiología del Suelo y Sistemas Simbióticos, Estación Experimental del Zaidín, Consejo Superior de Investigaciones Científicas (CSIC), Profesor Albareda 1, P.C, 18008 Granada, Spain 
the presence of allophane and imogolite, and (ii) 'nonallophanic Andisols', when 2:1 layer silicates dominate in the clay fraction (Dahlgren et al. 2004). These soils have characteristics that make them an unusual group, such as processing a variable charge, low $\mathrm{pH}$, high phosphate (P) adsorption capacity, and high levels of soil organic matter (SOM), which is highly humified (Takahashi and Dahlgren 2016; Panichini et al. 2017; Wada 1985). Moreover, the high water holding capacity, low density (both particle and bulk densities), and high aggregate stability, among other traits, are originated due to the high SOM content. These different characteristics are largely the result of the presence of allophane and imogolite together with $\mathrm{Al}$ - and Fe-humus complexes. All of them have highly reactive surfaces, although such properties are more pronounced in non-allophanic soils (Takahashi and Dahlgren 2016; Dahlgren et al. 2004). The high reactivity of Andisols explains the accumulation of humic materials, $\mathrm{P}$ retention, and the high activities of $\mathrm{H}^{+}$and phytotoxic $\mathrm{Al}^{3+}$ observed in some places (Shoji et al. 1993; Seguel et al. 2013; Aguilera et al. 2017). Additionally, because of its small particle size and extensive surface area, the allophane has a large affinity for adsorbing organic substances particularly in the presence of cations (Ugolini and Dahlgren 2002).

The accumulation of SOM is a typical characteristic of Andisols (Wada 1985; Redel et al. 2015) which is visually evident by a soil darkening owing to the presence of humic substances (HS) (Ugolini and Dahlgren 2002). According to Takahashi and Dahlgren (2016), Andisols also retain relatively large amounts of SOM, accounting for about $1.8 \%$ of the global soil organic carbon. The above-mentioned large SOM accumulation in this type of soils is, in addition to the formation of stable mineral-humus complexes, derived from a combination of allophane materials and the high inputs of agricultural and forestry detritus (Neculman et al. 2013). This is the consequence of a fast rate of recalcitrant HS production, together with the unfavorable environmental conditions which limit an efficient microbial degradation of the newly formed organic compounds (Dubé and Stolpe 2016).

Humic substances are polyelectrolytes which are strongly bound to mineral matrix by means of specific adsorption by ligand exchange and bound together by polyvalent cations such as $\mathrm{Al}^{3+}$ and $/ \mathrm{or} \mathrm{Fe}^{3+}$, forming macromolecular complexes of high recalcitrance (Schnitzer 2000; Parfitt 2009; Medina et al. 2017). The mean residence time of SOM stabilized in Andisols is generally much longer than those from other soil types, ranging from 1000 to 5000 years before present (Torn et al. 1997). This aspect undoubtedly is one of the most important factors determining the low availability of $\mathrm{P}$ in those soils due to the accumulation of organic $\mathrm{P}$ forms. Therefore, an adequate and equilibrate SOM mineralization may be required to ensure a $\mathrm{P}$ availability which can maintain plant growth. However, there are certain adverse conditions which may lead to the inadequate microbial mineralization rates of
SOM in these soils. These conditions include (i) relatively low temperature and a microflora profile dominated by fungi and actinobacteria, as a consequence of acidity (Wada 1985); (ii) high concentrations of potentially toxic elements such as $\mathrm{Al}^{+3}$, $\mathrm{H}^{+}$, and sometimes Mn, which significantly affect the microbial biomass and activity; and (iii) the scarcity of available $\mathrm{P}$ and low base cation content. Another factor which determines SOM accumulation in allophanic Andisols is the high number and stability of soil aggregates, which physically limit microbial attack of carbon patches, found inside porous structures of the aggregates. In addition, the activities of hydrolytic enzymes which are adsorbed on the surface of mineral matrix have been found to be inhibited (Pajares et al. 2011). Based on these particular properties of volcanic soils that limit the low $\mathrm{P}$ availability, the projected global depletion of $\mathrm{P}$ resources will therefore require very specific approaches to sustainably manage the $\mathrm{P}$ pools in these soils.

The major constituents responsible for P sorption in allophanic Andisols are allophanic materials and Al-humus complexes in comparison with non-allophanic ones, where Al-humus complexes govern this process. Phosphorus sorption is highly $\mathrm{pH}$ dependent, being higher in Al-humus complexes in comparison with allophanic materials (Madeira et al. 2007). Different reports have concluded that this $P$ retention can produce higher or lower $\mathrm{P}$ availabilities, according to the quantities of $\mathrm{P}$ that is adsorbed. Therefore, as $\mathrm{P}$-sorption is highest at $\mathrm{pH} 3-4$, it is expected that lime application would decrease $\mathrm{P}$ adsorption with a concomitant increase in the levels of available P (Pardo et al. 1992). In summary, the high P fixing capacity of Andisols can be attributed to the high reactivity of the mineral matrix, along with SOM active groups through the formation of stable linkages between such surfaces and $\mathrm{Fe}$ or $\mathrm{Al}$ cations as metal bridges.

It is known that HS have two important binding sites of high reactivity: the carboxilic and phenolics groups, both with the capacity of forming stable chelates or complexes, primarily with polyvalent cations like $\mathrm{Al}^{3+}$ and $\mathrm{Fe}^{3+}$ (Gerke 1997). The complexing capacity of HS increases according to the degree of humification. Owing to the higher complexing capacity of $\mathrm{Al}$, the humification is usually higher with $\mathrm{Al}$ as a cation, compared to Fe (Hernández-Soriano 2012). Within this framework, it is important to take into account that a major fraction of the total soil $\mathrm{P}$ is as organic-P forms. This is noticeable in agricultural soils, where continuous fertilization has produced an important increase of this organic-P pool, which can be re-used following the implementation of the required management practices, aimed at enhancing microbiota activity.

\subsection{Volcanic Soils from Southern Chile}

In Chile, volcanic ash gives rise to soils over a range of humidities, from sub-humid to super-humid and with 
temperatures that are generally within the temperate range. The clay fraction is dominated by amorphous mineral compounds with a highly variable charge, which causes the soils to be strongly buffered against changes in $\mathrm{pH}$ and also provides an apparently high base exchange capacity. These soils range in acidity from around $\mathrm{pH} 6.7$ to 4.5 , but their base status may lie between 90 and 2\% (Casanova et al. 2013). Besoain (1985) also reported that many Chilean volcanic soils have considerable quantities of gibbsite, kaolin, and also amorphous silica like allophane, along with halloysite, a hydrous iron oxide. It has been also reported that some of these soils contain a high proportion of exchangeable $\mathrm{Al}$ and free $\mathrm{Al}$ $\left(\mathrm{Al}^{3+}\right)$ forms which produce phytotoxicity to Al-sensitive plant species or specific cropped genotypes (Seguel et al. 2013; Aguilera et al. 2018), especially the non-allophanic Andisols with high Al-humus complexes.

In Chile, the two main orders comprising soils derived from volcanic ashes are Andisols (young soils) and Ultisols (weathered soils). Although these volcanic soils possess many advantageous edaphic characteristics, they also have other properties which habitually constrain plant growth, owing to the soil mineral characteristics as previously mentioned (Besoain 1985; Casanova et al. 2013). These deleterious properties include high $\mathrm{P}$ adsorption capacity and high levels of highly humified SOM. Furthermore, in some instances, these soils can also have high acidity levels, which are mainly due to inadequate soil management, such as the excessive use of ammonium fertilizers, with the concomitant development of $\mathrm{Al}, \mathrm{Mn}$, and $\mathrm{H}^{+}$phytotoxicities (Mora et al. 2006). In addition, the dominance of fungal biomass, be free or symbiotic, compared to total microbial biomass in volcanic soils contributes to render them highly reactive (Zunino et al. 1982a, b; Morales et al. 2011). Therefore, these characteristics and their interactions create highly reactive environments, especially in relation to $\mathrm{P}$ sorption.

Chilean Andisols have characteristics which are reflected in the following biological properties, which can help to understand the complexity of the overall biogeochemical cycles in such habitats, like (a) strong stabilization of indigenous organic matter (Mora and Canales 1995; Mora et al. 2006; Neculman et al. 2013; Panichini et al. 2017) or organic compounds (Zunino et al. 1982a) when they are added to the soils; (b) high rates of microbial synthesis of humic-type macromolecules (Borie and Zunino 1983); (c) high enzymatic activities including urease (Borie and Fuentealba 1982), phenoloxidase (Peirano et al. 1987), and acid phosphatase (Rubio et al. 1990; Alvear et al. 2006; Aguilera et al. 2018) among others, and (d) high presence and activity of mycorrhizal fungi in both agricultural and forest soils (Etcheverria et al. 2009; Marín et al. 2016).

Chilean volcanic soils have geologically high amounts of total P (Borie and Zunino 1983; Escudey et al. 2001; Velásquez et al. 2016), but the very low $P$ availability is mainly due to the slow diffusion and high fixation capacity of these soils, and consequently, this nutrient is the major limiting factor for plant growth and their agronomic use (Borie and Rubio 2003). The main mechanisms involved in such fixation processes have been widely investigated, using short-time equilibria procedures (Vistoso et al. 2012). The main conclusion has been that $\mathrm{P}$ retention in these soils is mainly due to the ability of allophane to strongly adsorb the phosphate, specifically by ligand exchange (Parfitt 1989; Pigna and Violante 2003). Concomitant with the high fixation capacity, farmers often apply P fertilizers in excess of crop requirements, in order to obtain high yields. This leads to a building-up of an important P reservoir of residual P (P-bank), which is then accumulated under different $P$ forms, mainly organic, which differ in lability and availability (Borie and Zunino 1983; Borie and Rubio 2003). In a recent study on the nature of such $\mathrm{P}$ accumulation in volcanic soils, Velásquez et al. (2016) have reported that residual $P$ accounted for $45-$ $63 \%$ of the total soil $\mathrm{P}$, of which $53-77 \%$ was as inorganic $\mathrm{P}$ forms. The organic $\mathrm{P}$ accounted for $21-42 \%$ of soil $\mathrm{P}$, the majority of which occurred as myo- (16\%) and scylloinositol hexakisphosphate (10\%), which concurs with a recent review of Menezes-Blackburn et al. (2018), whose data analyses of 251 soils worldwide from 41 publications found that organic P represents around $30-40 \%$ of total soil P. These findings provide the basis for the development of new approaches to improve $\mathrm{P}$ mobilization and P-use efficiency in sustainable agriculture. With appropriate soil management, a portion of this P-bank could be mobilized and made available for plant growth, thereby reducing the requirement for the application of additional soluble $P$ fertilizers.

It has been estimated that only $10-20 \%$ of the $\mathrm{P}$ applied is taken up by crops during the first year and the residual is fixed to the soil colloid surfaces or precipitated by $\mathrm{Al}$ and $\mathrm{Fe}$ (Campos et al. 2018). The amount and nature of $P$ forms accumulated in Chilean volcanic soils have been studied for many years by our group. We can conclude that the fate of P fertilizers in volcanic soils is the formation of (a) variscite-like minerals (Borie and Zunino 1983), (b) organic $P$ as inositolpenta- and hexaphosphate (Borie et al. 1989; Velásquez et al. 2016), and (c) macromolecular-P associated to fulvic- and humic-like compounds (Borie and Zunino 1983; Borie and Rubio 2003) where the bulk has a MW higher than $100 \mathrm{kD}$ (Borie et al. 1989). Therefore, $\mathrm{P}$ content of almost all cultivated and fertilized soils has increased over the years and the extent of such accumulation has depended on the fertilizer application rate, frequency of application, the adsorptive capacity of soils matrix surfaces, as well as on the microbial activity, especially microorganisms involved in P cycling (George et al. 2018; Menezes-Blackburn et al. 2018). Owing to these factors, several studies have been carried out in Chilean volcanic soils (Borie and Zunino 1983; Borie and Rubio 1999; Escudey et al. 2001; Redel et al. 2008) in order to increase the understanding of the nature of $\mathrm{P}$ 
accumulation, resulting from the annual application of $\mathrm{P}$ fertilizers. The potential lability of this soil P-bank may provide an alternative to increasing its availability and could also be included as an important P pool in agricultural management of improved utilization of accumulated P fertilizers (Redel et al. 2008). Therefore, studies related to soil management such as tillage, crop rotations, fertilization, and lime application, as well as with mycorrhizal biology, would play an invaluable role in P uptake efficiency by crops grown in volcanic soils (Borie et al. 2006).

Lability of P forms in Ultisols fertilized with and without phosphate and differing in crop rotation and tillage systems has been reported early by our group (Castillo et al. 2006). This report showed that after 4 years of cultivation, the total $P$ increased by $25 \%$ and that the bulk of this $\mathrm{P}$ was accumulated under moderately labile $\mathrm{P}$ and non-labile $\mathrm{P}$ (Castillo et al. 2006). No-tillage produced the largest soil surface $P$ accumulation, mainly as inorganic and microbial-P (Redel et al. 2008, 2011). When Lupinus albus was used as pre-crop in an annual rotation, there were increases in phosphatase activity (the enzyme involved in organic $\mathrm{P}$ hydrolysis for rendering $\mathrm{P}$ more available), organic and labile P levels, as well as increases in mono and diester-P concentrations (Redel et al. 2008). In summary, the continuous applications of $\mathrm{P}$ in amounts exceeding crop acquisition inevitably result in its accumulation in those soils.

\subsection{Nature of $P$ in Chilean Volcanic Soils}

In the early 1980s, a screening of field samples of fertilized and the corresponding unfertilized allophanic Andisols from southern Chile of the main soil series was conducted, to determine the total $\mathrm{P}$ content and to quantify the amounts of inorganic $\mathrm{P}(\mathrm{Pi})$ and organic $\mathrm{P}(\mathrm{Po})$, together with the nature of the different $\mathrm{P}$ compounds that mainly constitute the Po fraction. As expected, total and available $\mathrm{P}$ were higher in fertilized plots (Borie and Zunino 1983), especially in places where $\mathrm{P}$ fertilizers were applied annually. In addition, in the soils fertilized with inorganic $\mathrm{P}$ sources, Po was also higher as well as P linked to both humic and fulvic acids (Borie and Rubio 2003). The $P$ was accumulated on average at a total $P$ of $728 \mathrm{mg} \mathrm{kg}^{-1}$ through successive applications of phosphate fertilizers, of which about $65 \%$ was organic or in some way linked to SOM.

For a better understanding of the nature of Po in volcanic soils, a representative screening of nine soils under grassland (from La Araucanía, Los Ríos, and Los Lagos Regions) was performed for determining the total Po, $\mathrm{P}$ associated to humic (HA-P), and fulvic acids (FA-P) and also the contents of inositolphosphates (INP). Interestingly, 53\% of $\mathrm{P}$ was found to be Po, from which the bulk was associated with HA-P (mean: 63\%) and constituting a pool of macromolecular-P associations. Plants and microorganisms are able to access this pool of macromolecular-P, via biochemical mechanisms to mineralize and thereby increasing the $\mathrm{P}$ bio-availability (Borie and Rubio 2003). The high correlation between Po and HA-P found in that study suggests that Pi from fertilizers are being included in the INP fraction and that organic-mineral complexes form stable macromolecular P-associations, making it unlikely to be mineralized by microorganisms or by root and microbial phosphatases. These findings concur with those reported by Baker (1977) who found a 71\% of HA-P in New Zealand soils and are also in agreement with Gerke (2010) that suggest humic-metal-P associations can account for more than $50 \%$ and, in some cases, more than $80 \%$ of the $\mathrm{P}$ in soil. The same soil samples were subjected to a drastic alkaline extraction using Irving and Cosgrove procedure (1982) to determine the proportion of $\mathrm{P}$ as inositol penta- and hexaphosphates. Despite the severe extracting conditions, which could produce significant hydrolytic effects with lesser INP amounts, the levels found were relatively high. Therefore, results showed that INP accounted for a mean of 58\% of total P, thereby suggesting that these compounds are associated in some way to humic materials as part of HA-P and extracted together (Borie et al. 1989). This is congruent with Hong and Yamane (1981) who found 70\% of Po as INP in an Andisol from Japan. Therefore, with such high levels of Po, the authors demonstrated that $\mathrm{P}$ associated with humic materials constitute a greater proportion of Po extracted by resins or sodium hydroxide. More recently, Gerke (2015) reported that a large proportion of INP is found in the high molecular fraction associated with HS, this association being very strong according to its refractory behavior when subjected to the hydrolytic action of concentrated alkali or acid solutions. It is known that INP-Fe and INP-Al are insoluble, having similar solubility like the corresponding phosphates. As INP levels in these soils are difficult to determine without the interference of HA, the modern methodology for a most accurate determination involves the use of mild extractants, exchange resins and EDTA and further application of ${ }^{31} \mathrm{P}-\mathrm{NMR}$ spectroscopy (Redel et al. 2011, 2015).

Inositols have low MW compared to humic materials. For estimating the molecular weight of HA-P extracted from grassland, a Typic Distrandepts soil was selected, extracted, and subjected to dialysis and separation by gel permeation (Borie et al. 1989). In the purified extract obtained, according to the Steward and Oades method, the absorbance of HA and $\mathrm{P}$ after digestion with $\mathrm{NaBrO}$ was measured. Results showed that approximately $96 \%$ of HA-P had a molecular weight $>$ $100 \mathrm{kD}$ and only about $2 \%$ had a molecular weight $<60 \mathrm{kD}$. Nonetheless, a HA-P fraction near $5 \%$ was not associated with $\mathrm{P}$, particularly in the range of 60 to $100 \mathrm{kD}$. Ash analysis of metals after combustion of HA-P, which included INP, indicated that $\mathrm{Fe}$ and $\mathrm{Al}$ were intimately associated with both fractions. These results indicate that in the extraction of INP using traditional methodology, also other humic materials are being co-extracted. These constitute a large and complex 
structure of polymeric nature, including metal bridges, which at present remains unresolved due to a lack of direct evidence. Subsequently, Escudey et al. (2001) and Briceño et al. (2004) working with ten volcanic soils (two Ultisols and eight Andisols) employing ${ }^{31} \mathrm{P}-\mathrm{NMR}$ spectroscopy as a new approach for characterizing soil $\mathrm{P}$, found a range of 17 to $64 \%$ Po as INP, being higher in Andisols. Coincidentally, Redel et al. (2008) applying this same methodology to extracts in an Ultisol and in an Andisol found that in the former soils, the Pi forms were greater in relation to Po forms. This was in contrast to the Andisol, where Po forms prevailed with the presence of monoester-P, and INP was the main component. These findings are in accordance with those reported by McLaren et al. (2015) in a recent study, where the speciation of organic $\mathrm{P}$ was measured by ${ }^{31} \mathrm{P}-\mathrm{NMR}$ in dialyzed fractions into two molecular weight ranges $<$ or $>$ to $10 \mathrm{kD}$, with both spectra being comparatively very different. Therefore, fractions from low molecular weight showed sharp peaks corresponding to myo- and scillo-inositol hexakisphophate, contrasting with broad peak in the extract from high molecular weight with a dominance of $\mathrm{P}$ bound to macromolecular structures, with values ranging from 61 to $73 \%$ of soil Po across the five soils analyzed. Surprisingly, the higher amount corresponded to the soil with the highest Al-oxalate content, suggesting strong linkages to humic compounds.

Phospholipids that enter the soil mainly through microbial and plant cell degradation are usually found in agricultural soils at quantities less than $5 \mathrm{mg} \mathrm{P} \mathrm{kg}^{-1}$ and in the range from 0.5 to $7 \%$ of total Po (Senesi and Loffredo 1992). This is indicative of a high decomposition rate and consequently represents the very labile $\mathrm{P}$ source for microbial growth. In a study of lipid-P in cropped and non-cropped Andisols, a range from 0.06 to $0.72 \%$ was found without differences between fertilized or unfertilized soils (Borie and Barea 1985). Finally, the $\mathrm{P}$ forming poly-P has not been analyzed in volcanic soils from Chile, which can represent an interesting P source, considering the relative importance of fungal presence in this kind of soils. In particular, poly-P is important for arbuscular mycorrhizal (AM) fungi, because of its capacity for P transport and storage in vacuoles.

\subsection{Lability of $P$ in Volcanic Soils}

Under natural conditions, many plants are able to thrive in soils which are poor in available $\mathrm{P}$, with the use of mechanisms to scavenge for this nutrient. These mechanisms include, among others, the exudation of organic compounds from the roots. It is feasible to mimic these root exudates in the laboratory, with the use of selective chemical reagents, to allow the solubilization or desorption of $\mathrm{P}$ forms, which are not usually directly available to plant roots. The most recognized is the sequential extraction procedure of Hedley et al. (1982) whereby P is separated into Pi and Po forms, differing in lability and consequently in plant availability. In this method, a progression of stronger reagents and conditions are used to mimic the chemical reactivity produced in the rhizosphere. Therefore, the use of water extraction with or without the use of an anion exchange resin determines the most bioavailable $\mathrm{P}$ fraction constituting $\mathrm{P}$ in the soil solution, whereas further application of a mild reagent such as diluted $\mathrm{NaHCO}_{3}$ gives information about the lability of Pi and Po forms which can be easily used by plants. Subsequently, the extraction with diluted $\mathrm{NaOH}$ provides information about the chemisorbed and internal $\mathrm{P}$, while the extraction with diluted $\mathrm{HCl}$ provides more information about $\mathrm{P}$ which is occluded in the soil matrix. All the $\mathrm{P}$ remaining in the soil after these extractions with the above reactants corresponds to "residual P", which contains significant $\mathrm{P}$ quantities and represents forms of $\mathrm{P}$ that are highly recalcitrant (Velásquez et al. 2016; McLaren et al. 2015; Menezes-Blackburn et al. 2018). For example, after application of Hedley procedure on two fertilized and nonfertilized volcanic soils (Vilcún and Osorno soil series, Araucanía Region, Chile) it was found that over $50 \%$ of $\mathrm{P}$ fertilizer was accumulated as residual $\mathrm{P}$, with significant quantities being detected in the chemisorbed fraction (Borie and Rubio 2003). These results, once again indicate that an important part of the Pi applied with fertilizers is accumulated under Po forms or integrating P macromolecular associations, differing in their potential bioavailabilities. Redel et al. (2008) reported similar findings, when applying the same fractionation scheme in soils from a crop rotation with contrasting soil tillage (conventional -CT- and non-tillage -NT-), thereby highlighting the higher lability observed in all the fractions, including residual P fraction when NT is applied. Another interesting result is the high lability of $\mathrm{P}$ fractions when lupine was used as a previous cultivation. It is known that white lupin can increase soil $\mathrm{P}$ availability through the exudation of citric acid and phosphatases by its cluster roots (Gilbert et al. 1999). In this regard, the inclusion of plant species like lupine in crop rotations in highly reactive soils, such as Andisols, is therefore a good strategy. This strategy not only represents a good alternative for increasing the lability and the efficiency of the applied $\mathrm{P}$ fertilizer, but also for the accumulated soil $\mathrm{P}$, resulting from yearly applications. Exudation of citric acid and acid phosphatase as an efficient strategy of root $\mathrm{P}$ acquisition has been also described by Delgado et al. (2013, 2014) in Embothrium coccineum proteoid roots when growing in volcanic soils.

In contrast to agricultural volcanic soils, the $\mathrm{P}$ forms in forest soils are mainly product of pedogenesis and $\mathrm{P}$ cycling processes. In this context, Redel et al. (2008) applied the Hedley methodology for studying the lability of $\mathrm{P}$ forms in soils from a pristine evergreen forest ecosystem, and an evergreen forest which was originally a pristine ecosystem but with a selective species clearing 50 years ago. Although both soils had around the same chemical properties as $\mathrm{pH}(5.0)$, 
organic $\mathrm{C}(15 \%)$, and Olsen $\mathrm{P}\left(2.3 \mathrm{mg} \mathrm{kg}^{-1}\right)$, the lability of $\mathrm{P}$ forms changed significantly as a product of forest management. Therefore, whereas Po represented about $80 \%$ of total $\mathrm{P}$ in the pristine forest in managed forest decreased to $55 \%$ (Redel et al. 2008). These results show that the higher microbial $\mathrm{P}$ mineralization was produced by human intervention affecting labile-Po (extracted with $\mathrm{NaHCO}_{3}$ ) and chemisorbed-Po (extracted with $\mathrm{NaOH}$ ). In a more recent study, Redel et al. (2015) compared P bioavailability in a Nothofagus rainforest Andisol with adjacent, clear-cut grassland with purpose to evaluate the effects of forestation on the lability of chemical fractions using Hedley procedure. The observed decrease in $\mathrm{pH}$ and Po suggests that soil acidification and Po mineralization are produced as a consequence of forest growth, which correlate with an increase in available P, microbial P-biomass, and phosphatase activity. When applying $\mathrm{P}$-fractionation methodology, an increase in the more labile $\mathrm{P}$ fractions $\left(\mathrm{P}-\mathrm{NaHCO}_{3}, \mathrm{P}\right.$ resin, and microbial $\left.\mathrm{P}\right)$ was observed. In congruence with the study of Redel et al. (2008), the bulk of $\mathrm{P}$ is linked to humus, as a macromolecular $\mathrm{P}$ association with high recalcitrance. Therefore, the lability of $\mathrm{P}$ forms will depend on a series of factors which should be taken into account, to optimize the utilization of $\mathrm{P}$ by plants, growing in low available $\mathrm{P}$ conditions.

\subsection{Acid Volcanic Soils, P Use Efficiency, and Arbuscular Mycorrhizae}

It is noteworthy that $\mathrm{P}$ uptake is generally only $10-20 \%$ of the total fertilizer applied in the first year and that a substantial part of the applied P accumulates in the soil as residual P, scarcely available to plants. Therefore, agronomic strategies for increasing P fertilizer availability to crops have been developed as by applications of liquid fertilizers or by strategic fertilizer placements (Ma et al. 2009). However, these agronomic strategies require modern technology and are relatively expensive. An alternative to relate low soil P levels with plant growth is to study the $\mathrm{P}$ acquisition/uptake/use efficiency, and in this area, some important advances have been made during the last decade, concerning to concept "P efficiency" (Campos et al. 2018). In this regard, breeding for P-efficient crop cultivars has been advocated due to its relatively low cost to provide benefits to both high and low-input systems (Rose et al. 2010). Despite the growing accumulation of knowledge in the field, there is still some controversy in the concept and measurement of efficiency, since it has many definitions, and moreover, different terms are often used for the same calculations and expressions (Bovill et al. 2013). Nowadays, two basic mechanisms for $\mathrm{P}$ efficiency are distinguished: (a) the internal efficiency of allocation/mobilization of $\mathrm{P}$ in order to produce biomass with lower input and (b) the plant's ability to acquire $\mathrm{P}$ from the soil, also known as $\mathrm{P}$ acquisition efficiency (PAE), representing the $\mathrm{P}$ efficiency with which cultivars acquire $\mathrm{P}$ from the soil $(\mathrm{PAE}=\mathrm{mg} \mathrm{P}$ taken up per plant) (Rose and Wissuwa 2012). The internal use efficiency or $P$ use efficiency (PUE) is here defined as the amount of P accumulated in the tissue per biomass unit (shoot and/or root) or grain produced (Rose and Wissuwa 2012). It is related to a range of metabolic modifications, which can ensue to reduce the $\mathrm{P}$ demand during plant development (Vaneklaas et al. 2012). Improving internal PUE can lead to a more resourceefficient use of $\mathrm{P}$, rather than increasing the uptake of potentially scarce $\mathrm{P}$ forms, which in theory will lead to lower $\mathrm{P}$ acquisition by crops and could therefore minimize the $\mathrm{P}$ fertilizer requirement and removal from fields. To date, no crop species or genotypes within species are known to be capable of reducing its net $\mathrm{P}$ uptake, if the demand for $\mathrm{P}$ has been reduced (Rose and Wissuwa 2012). In soils rich in adsorbed $\mathrm{P}$, which is observed in the majority of acidic volcanic soils, breeding programs focused on the optimization of $\mathrm{P}$ scavenging mechanisms would be a key role to improve P efficiency, and for this purpose, root traits should become very important (Campos et al. 2018), including the arbuscular mycorrhizae (AM).

Phosphorus status is a major factor to modulate root architecture, where the higher root-to-shoot ratio is the most evident change in plants experiencing $\mathrm{P}$ deprivation (Gruber et al. 2013). Phosphate presents a heterogeneous distribution (patches), given its high affinity for the soil matrix and, as the rhizosphere quickly becomes depleted of $\mathrm{P}$, the roots have to continually grow in order to find new "available $\mathrm{P}$ hotspots". The topsoil layer $(0-10 \mathrm{~cm})$ is the zone where $\mathrm{P}$ availability for plants and microorganisms is generally higher due to its poor mobility in soil. Important adaptations to access this richer environment are axial roots with a shallower angle, enhanced adventitious rooting, and greater density and dispersion of lateral roots and root hairs (Lynch 2007; Wang et al. 2004). These traits together with root length, diameter, and surface/volume comprise the most important causes of interand intra-specific genetic variation for root morphological traits for PAE. For example, during screening for traits with increased PAE, Manske et al. (2000) found that higher root length density in top soil of wheat crops was the most important root trait for P uptake, which was positively correlated with enhanced recovery of fertilized P. Moreover, basal roots in some legumes (such as bean and soybean) appear in distinct nodes or "whorls", which affect root growth angles and therefore the capacity for exploring the topsoil. Differences of up to $100 \%$ greater $\mathrm{P}$ acquisition can be found in common bean cultivars, as basal root whorl number varies among genotypes (Lynch 2007). However, plants with higher density of roots in top soil and shallower angles have lower water use efficiency, as water is usually more abundant in deeper layers under drought conditions (Ho et al. 2005).

Another important root trait is the association with AM fungi. In this sense, Seguel et al. (2015) showed an improved 
PAE in mycorrhizal treatments, and the largest increase with AM fungi was observed in a P-efficient Hordeum vulgare cultivar in an acidic non-limed soil. The increase was smaller in limed soil and the PAE was increased in a P non-efficient barley cultivar, principally by liming. In the same study, the PAE was influenced by the barley cultivar and by AM interactions. Despite the above, screening and phenotyping for these traits remain a complex challenge, as soil-based systems are high-technology intensive and hydroponic/aeroponic systems cannot emulate the complexity of the processes occurring in the soil. Therefore, genotypes selected in this way do not always show their superiority in field trials. Moreover, recently, Seguel et al. $(2016,2017)$ have carried out field experiments with winter wheat cultivars to study Al-P interactions on genotypes with contrasting Al tolerance. In this study, the Altolerant genotypes were most effective when $\mathrm{P}$ fertilizer was added, suggesting that plant traits such as Al tolerance, PAE, and AM colonization potential can interact to jointly overcome the adverse acid soil conditions. Specifically, the authors reported that the Al-tolerant wheat genotypes (TCRB14 and TINB14) exhibited higher PAE and yield than the Alsensitive one (STKI14). However, the Al-tolerant genotypes differed in response-PAE relationships, with evidence that genotype TINB14 may be less affected by low soil P, whereas it allocates more to grain yield when $\mathrm{P}$ fertilizer is applied. In addition, based on the identification of acid-soil-resistant AM fungi, and also strains that seem to be related to improved wheat PAE, exudation of organic acids and acid phosphatases may form the basis of breeding programs to develop new genotypes, based on specific AM fungal ecotypes aimed to the management of acid soils with high Al levels.

\subsection{Arbuscular Mycorrhizae in Volcanic Soils}

It is well-known that plants growing in soils with scarce available P develop some mechanisms or root strategies for scavenging this nutrient from unavailable sources. These include (a) the modification of root structure to enhance the exploration of a greater soil volume (Lynch 2007; Vance et al. 2003), (b) the exudation of organic acids and phosphatases to liberate Pi adsorbed in soils matrix and also to hydrolyze Po (Lynch, 2007), and (c) lastly, but perhaps the most powerful and extensive adaptive mechanism is the symbiotic association of almost all plant roots, with soil fungi forming mycorrhizas, with a greater soil exploration capacity (Smith and Read 2008). As stated above, the volcanic soils are deficient in available P, but they have high amounts of non-labile $\mathrm{P}$ pools, which can be a source of potentially available P. For a long time, our research group has been studying the key role played by the AM symbiosis in Chilean Andisols, mainly in acquiring $\mathrm{P}$ in plants growing under different soil management practices, among others such as tillage systems, crop rotation, the use of rock phosphate, and lime application. For example, the effect of the native AM fungus Glomus etunicatum on wheat growth was studied in a natural volcanic soil fertilized with soluble $\mathrm{P}$ and compared with partially acidulated rock phosphate (pa-RP) at two rates: 17 and $86 \mathrm{~kg} \mathrm{P} \mathrm{ha}^{-1}$ (Rubio et al. 2003). The authors showed that AM inoculation significantly increased the P acquisition, densities of spores and extraradical mycelium, root $\mathrm{P}$-ase and shoot $\mathrm{P}$ concentration, when pa-PR was added especially at the upper level. The same beneficial effects on Pacquisition and plant growth with Glomus etunicatum inoculation have been obtained by Borie and Rubio (1999) and Mendoza and Borie (1998) with barley growing in an Andisol. Decreases in $\mathrm{Al} / \mathrm{P}$ and $\mathrm{Al} / \mathrm{Ca}$ ratios in shoots indicated that AM symbiosis enhanced Al tolerance to a higher degree in comparison with lime amendments $\left(2 \mathrm{Mg} \mathrm{ha}^{-1}\right)$.

On the other hand, it is known that tillage modifies soil physical and chemical environments in which microorganisms live thereby affecting their number, diversity, and activity (Mathew et al. 2012). Thus, when soil is disturbed with the use of plow, a great impact on biological properties is produced. This is due to higher oxidation conditions with greater SOM mineralization rate, together with the disruption of AM fungal mycelia (Cornejo et al. 2009). This rupture consequently generates a decrease of the benefits produced by the symbiosis, especially nutrient acquisition and the stability of soil aggregates. In order to demonstrate some of these characteristics, a short 2-year-course crop rotation was performed, consisting of a succession of wheat and oat in a Chilean typic Ultisol, for studying the influence of conventional (CT) and non-tillage (NT) (Castillo et al. 2006). Different fungal parameters were measured, including spore number, hyphal density and diversity of AM fungal communities. Results showed that NT systems are producing early beneficial effects on mycorrhizal characteristics like an increase in root colonization, viable hyphae, spore number, and species richness. These were evident, even before any soil chemical or physical changes, which are usually only visualized after 5-6 years of the application of NT (Curaqueo et al. 2011). The same beneficial behavior has been observed by Borie et al. (2006) in a study on an Ultisol with four tillage systems (no-till, NT; reduced tillage, RT; conventional tillage with retained stubble, CTS; and conventional tillage with stubble burning, CTB). In all the systems, the AM fungal spores number, total and active hyphae, and AM root colonization were measured before (BS) and after 6 months of grass sowing (AS) in a rotation which included wheat and grass. The findings can be summarized as follows: (a) CT drastically reduced spore number, hyphal density, and AM root colonization and even $\mathrm{P}$ concentration in shoots; (b) as expected, AM root colonization and spore number were not affected but total and active hyphae were severely reduced when RT was applied, suggesting that soil disruption is much lesser and can be viewed as an useful tool in compacted soils; (c) stubble burning decreased spore number but the other fungal propagules were not affected, which 
suggests that the fire effect was only at top soil layer and not deeper, where the bulk of hyphae and colonized roots are found; and (d) the fungal propagules left in the soil after each crop were significantly (wheat and grass) different. Whereas the wheat left more spore numbers, the grass left a higher hyphal density. In summary, these effects are evident as early indicators of changes that are produced in the microbial system when soil is subjected to contrasting agricultural managements, like tillage.

In addition to benefits produced by AM symbiosis, the increasing plant mineral nutrition, mainly the acquisition of $\mathrm{P}$, the AM extraradical hyphae also contribute to the formation and maintenance of soil aggregates (Borie et al. 2008; Curaqueo et al. 2011) through hyphal network and the production of glomalin, a glycoprotein which act as a glue agglutinating soil particles (Cornejo et al. 2008, 2017). Soil aggregation is the result of rearrangement, flocculation, and cementation of soil particles where SOC, polycations, clay, minerals, and especially biota are playing a key role. The most important soil microbial originated organic compounds on aggregation are polysaccharides and glomalin (Bronick and Lal 2005). Polysaccharides have a transient effect, functioning as bridges to bind soil particles or acting as glue for maintaining particles together. However, the most permanent effect is produced by glomalin, because there are highly significant relationships between soil aggregation stability and total glomalin in Andisols and Ultisols from southern Chile (Borie et al. 2008; Valarini et al. 2009; Aguilera et al. 2011; Marín et al. 2016). This is noteworthy, since the adaptation of the rhizosphere directly and indirectly influences the $\mathrm{P}$ availability for the plant use. Therefore, it is essential to know the diversity and functions of the AM fungi in the natural communities of volcanic soils form Southern Chile.

\subsection{Arbuscular Mycorrhizal Fungal Diversity and Functioning in Volcanic Soils from Chile}

Although AM fungi promote tolerance to the host plant when growing under environmental stresses, it is essential to consider that a high concentration of $\mathrm{Al}$ is congruent with a low $\mathrm{P}$ availability in acidic volcanic soils (Takahashi and Dahlgren 2016). These conditions decrease the germination of AM fungi spores and subsequently the root colonization of host plants. On the other hand, spores of some AM fungi have been found to germinate, resulting in effective root colonization even at extreme Al concentrations (Rohyadi 2005). Attenuation of Al toxicity is related to the free $\mathrm{Al}$ availability and may be favored not only by $\mathrm{Al}$ binding to $\mathrm{AM}$ fungal structures such as spores, hyphae, and vesicles (Aguilera et al. 2011; Rufyikiri et al. 2000), but also Al can be immobilized by the AM-produced glomalin (Aguilera et al. 2011; Seguel et al. 2013, 2015). Several reports have focused on determining the capacity of glomalin for metal sequestration, presumably due to complex formation (González-Chávez et al. 2004; Cornejo et al. 2008, 2017). More specific analyses have been implemented in the study of glomalin, in order to produce analytical signals without the interference of humic compounds present in soil, for which inert substrates having separate zones of rhizosphere and hyphosphere have been used (Nichols 2010; Aguilera et al. 2018). These types of studies have allowed the inclusion of an $\mathrm{Al}$ Tolerance Index, related to the AM colonization, as this parameter is related to the PUE in some Al-tolerant and Pefficient wheat genotypes (Aguilera et al. 2018). In this regard, the inoculation with AM fungi appears as another management alternative, because of the well-documented AM contribution to plants growing in acidic soils, the contribution to the $\mathrm{Al}$ tolerance and also in the efficient use of $\mathrm{P}$ (Seguel et al. 2013; Aguilera et al. 2015; Campos et al. 2018). For the above, the AM fungal diversity must be highlighted as an important component in soil fertility, since this composition and functionality can be modified by management practices (Cornejo et al. 2009). In addition, the study of AM fungal diversity and structure provides basic information to assess the impacts generated by some agricultural practices on AM fungal communities (Oehl et al. 2010). These impacts directly affect the AM fungal propagules, glomalin-related soil protein (GRSP) and AM fungus/plant interactions (van der Heijden et al. 1998; Oehl et al. 2004). The latter is based on different compatibilities of AM fungal species with their hosts, and their variable functionality under certain conditions (van der Heijden et al. 1998; Aguilera et al. 2015, 2017). The variability in AM fungal function is even evident at the intra-specific level. Intra- and inter specific functional variability has been reported in AM fungi species in regard to fungal diversity and their effects on plants exposed to high Al levels in acid soils from southern Chile (Aguilera et al. 2017; Castillo et al. 2016). Moreover, plants inoculated with AM fungi in soils with high $\mathrm{Al}$ content and low $\mathrm{P}$ availability have shown higher growth than noninoculated plants (Seguel et al. 2012).

While measuring community-level physiological adaptations of AM fungi to high $\mathrm{Al}$ stress and low $\mathrm{P}$ availability is a good starting point, the AM fungal community itself must be measured in order to make more precise inoculation recommendations (Barea et al. 2013; Aguilera et al. 2017). These recommendations are not only for the management of indigenous AM fungal populations, but also for the isolation, reproduction and design of AM fungi based inocula, aimed to cope with specific stress factors, such as high $\mathrm{Al}$ levels or low $\mathrm{P}$ availability as the particular case of Chilean volcanic soils.

\section{Conclusions and Prospects}

The aim of this paper was to highlight and summarize the range of diverse, continuing projects and different approaches studied in Chilean volcanic soils in order to provide new 
knowledge for making the production of thousands of hectares, much more sustainable. In this regard, the main objective was to overcome the two main harmful stresses to plant growth, which are high levels of exchangeable $\mathrm{Al}$ and the scarcity of bio-available P. Up to the last decade of twenty century, the solution for minimizing these two limitations has been the application of massive amounts of soluble fertilizers. The excessive use of these fertilizers over many decades has led to the accumulation of soil $\mathrm{P}$ pools at levels which are environmentally unsound, because they increase the risk of watercourse pollution and the potential for eutrophication. Therefore, it is imperative to reduce soil $\mathrm{P}$ to levels to the minimum acceptable standard from an environmental and productive point of view. With the application of new technological tools, we must face a double challenge: on the one side, the uncontrolled phosphate applications must be avoided, and on the other side, the mobilization of the huge amounts of accumulated residual $\mathrm{P}$ must be increased. According to estimations reported by McLaren et al. (2015), the residual $\mathrm{P}$ could reach into the first $50 \mathrm{~cm}$ of the soil profile, representing up to 29 gigatonnes of soil P. This residual $\mathrm{P}$ comprises phosphomonoesters and macromolecular $\mathrm{P}$ compounds of unknown structure and degradation rate by soil microbiota, which in some way could alleviate $\mathrm{P}$ overuse when adequate management or technology is applied.

Several approaches are being applied to face this problem in Chilean volcanic soils, which can be broadly classified according the processes involved in (a) management practices and (b) technologies focused to increase P-efficiency in plants, bearing in mind the ban of GMO's in Chile. With regard to the first approach, the use of cover crops in non-till farming, the improved strategies for fertilizer application, manure recycling especially in grassland soils, the benefits of using composted crop residues and sludge, the utilization of pre-crops adapted to grow in poor P-habitats, among others, emerge as the new agricultural practices, aimed at decreasing the levels of Pfertilizer applications to crops and employed by a new generation of farmers. With regards to the second approach, a wide range of technological solutions could be envisaged to produce plants with higher P-use efficient, either as free-standing species or associated to rhizosphere free-living or symbiotic microorganisms. There is a huge field for future breeding research, to manage the main root physiological traits like architecture, exudation of organic anions and phosphatase or increasing internal P-use, the use of microbial inoculants, especially mycorrhizal fungi. The use of AM fungi in extensive agriculture is a dream which originated in the last century, but unfortunately, the complexity of biochemical processes performed in the rhizosphere and microbial competition has precluded the success of introduced AM fungal strains when applied alone or in consortia, being an important bottleneck in the establishment of populations persisting over multiple seasons. On the other hand, generation of seeds with minor $\mathrm{P}$ requirements but without affecting germination would be another challenge to breeders.

Perhaps the most interesting approach to be applied in the conditions of Chilean volcanic soils (high total-P including the significant amounts of residual $\mathrm{P}$ together low available $\mathrm{P}$ ) would be the improvement of $\mathrm{P}$ cycling, through an appropriate tillage and rotation management, to include cover crops and cash crops (like lupin, buckwheat, amaranthus, quinoa), all of them with high efficiency in $\mathrm{P}$ acquisition. Dealing with soil microbial biomass and recycling crops and wastes residues could be other interesting tools for mobilizing some fractions of residual P. An attractive point of view for "closing the loop on P loss from intensive agricultural soils" has recently been suggested by Zhang et al. (2018) in terms of manipulating soil conditions for increasing $\mathrm{P}$ immobilization in microbial biomass (MB-P), which can be released to the soil solution during microbial turnover. According to this view, the turnover time of MB-P in the field can range from tens of days to 1 year (Zhang et al. 2018), depending on several environmental conditions like climate, season, $\mathrm{P}$ application (forms and rates). Some studies have estimated that flux from microbial biomass can arrive near $37 \mathrm{~kg} / \mathrm{ha}$ in grassland soils (Liebish et al. 2014). Generally, with small C/P ratio in microbial biomass due to the excessive application of $\mathrm{P}$ fertilizer, it is difficult to observe P immobilization. On the contrary, by raising this $\mathrm{C} / \mathrm{P}$ ratio, it is possible to force microbial immobilization, thereby avoiding the $\mathrm{P}$ losses which could be the benefits produced by Lupinus albus as pre-crop or as intercrop, where citric acid production by root could supply $\mathrm{C}$ and $\mathrm{P}$ for microbial growth and $\mathrm{P}$ immobilization.

Funding Information Financial support was received from the FONDECYT 1170264 (P. Cornejo), FONDECYT 11160385 (A. Seguel), and FONDECYT 11170641 (P. Aguilera) grants from the Comisión Nacional de Investigación Científica y Tecnológica (CONICYT), Chile. A. Valentine was supported in Chile by a grant from the MEC Program No80170023 (CONICYT). P. Cornejo also thank to CONICYT/FONDAP/15130015.

\section{Compliance with Ethical Standards}

Conflict of Interest The authors declare that they have no conflict of interest.

\section{References}

Aguilera P, Borie F, Seguel A, Cornejo P (2011) Fluorescence detection of aluminum in arbuscular mycorrhizal fungal structures and glomalin using confocal laser scanning microscopy. Soil Biol Biochem 43:2427-2431

Aguilera P, Cornejo P, Borie F, Barea JM, von Baer E, Oehl F (2015) Diversity of arbuscular mycorrhizal fungi associated to Triticum aestivum L. plants growing in an andosol with phytotoxic aluminum levels. Agric Ecosyst Environ 186:178-184 
Aguilera P, Marín C, Oehl F, Godoy R, Borie F, Cornejo P (2017) Selection of aluminum tolerant cereal genotypes strongly influences the arbuscular mycorrhizal fungal communities in an acidic andosol. Agric Ecosyst Environ 246:86-93

Aguilera P, Larsen J, Borie F, Berrios D, Tapia C, Cornejo P (2018) New evidences on the contribution of arbuscular mycorrhizal fungi inducing Al tolerance in wheat. Rhizosphere 5:43-50

Alvear M, Pino M, Castillo C, Trasar-Cepeda C, Gil Sotres F (2006) Effect of no-tillage on some biological activities in an Alfisol from southern Chile. J Soil Sci Plant Nutr 6:38-53

Baker RT (1977) Humic acid associated organic phosphate. N Zeal J Soil Sci 20:439-441

Barea JM, Pozo MJ, Azcón R, Azcón-Aguilar C (2013) Microbial interactions in the rhizosphere. In: de Bruijn F (ed) Molecular microbial ecology of the rhizosphere. Willey-Blackwell, USA, pp 29-44

Besoain E (1985) Mineralogía de los suelos volcánicos del centro-sur de Chile. In: Tosso J (ed) Suelos Volcánicos de Chile. INIA, pp 107-302

Borie F, Barea JM (1985) Occurrence of lipid-P in volcanic ash derived soils of Chile. Agrochimica 28:317-324

Borie F, Fuentealba R (1982) Biochemistry of soils derived from volcanic ashes. II. Urease activity. Agric Tec (Chile) 42:135-142

Borie F, Rubio R (1999) Effects of arbuscular mycorrhizae and liming on growth and mineral acquisition of aluminum-tolerant and Alsensitive barley cultivars. J Plant Nutr 22:121-137

Borie F, Rubio R (2003) Total and organic phosphorus in Chilean volcanic soils. Gayana Bot 60:69-78

Borie F, Zunino H (1983) Organic matter-phosphorus associations as a sink in P-fixation processes in allophanics soils of Chile. Soil Biol Biochem 15:599-603

Borie F, Zunino H, Martínez L (1989) Macromolecule-P associations and inositol phosphates in some chilean volcanic soils of temperate regions. Commun Soil Sci Plant Anal 20:1881-1894

Borie F, Rubio R, Rouanet JL, Morales A, Borie G, Rojas C (2006) Effects of tillage systems on soils characteristics, glomalin and mycorrhizal propagules in a Chilean Ultisol. Soil Tillage Res 28:253-261

Borie F, Rubio R, Morales A (2008) Arbuscular mycorrhizal fungi and soil aggregation. J Soil Sci Plant Nutr 8:9-18

Bovill WD, Huang CY, McDonald GK (2013) Genetic approaches to enhancing phosphorus-use efficiency (PUE) in crops: challenges and directions. Crop Pasture Sci 64:179-198

Briceño M, Escudey M, Galindo G, Borchard D, Chang A (2004) Characterization of chemical phosphorus forms in volcanic soils using ${ }^{31}$ P-NMR spectroscopy. Commun Soil Sci Plant Anal 35: $1323-1335$

Bronick CJ, Lal R (2005) Soil structure and management: a review. Geoderma 124:33-22

Campos P, Borie F, Cornejo P, López-Raez JA, López-García A, Seguel A (2018) Phosphorus acquisition efficiency related to root traits: is mycorrhizal Symbiosis a key factor to wheat and barley cropping? Front Plant Sci 9:752

Casanova M, Salazar O, Seguel O, Luzio W (2013) The soils of Chile. Springer Verlag, London

Castillo C, Rubio R, Rouanet JL, Borie F (2006) Early effect of tillage and crop rotation in arbuscular mycorrhizal fungal propagules in an Ultisol. Biol Fertil Soils 43:83-92

Castillo CG, Borie F, Oehl F, Sieverding E (2016) Arbuscular mycorrhizal fungi biodiversity: prospecting in southern central zone of Chile. A Review. J Soil Sci Plant Nutr 16:11-24

Cornejo P, Meier S, Borie G, Rillig MC, Borie F (2008) Glomalin-related soil protein in a Mediterranean ecosystem affected by a copper smelter and its contribution to cu and $\mathrm{Zn}$ sequestration. Sci Total Environ 406:154-160

Cornejo P, Rubio R, Borie F (2009) Mycorrhizal propagules persistence in a succession of cereals in an Andisol disturbed and undisturbed, fertilized with two nitrogen sources. Chilean J Agric Res 69:426434
Cornejo P, Meier S, Durán P, García S, Ferrol N, Borie F (2017) Contribution of Bradford-reactive soil protein to the copper sequestration in a cu-polluted soil using Oenothera picensis. J Soil Sci Plant Nutr 17:1-8

Curaqueo G, Barea JM, Acevedo E, Rubio R, Cornejo P, Borie F (2011) Effects of different tillage system on arbuscular mycorrhizal fungal propagules and physical properties in a Mediterranean agroecosystem in Central Chile. Soil Tillage Res 113:11-18

Dahlgren RA, Saigusa M, Ugolini FC (2004) The nature, properties and management of volcanic soils. Adv Agron 82:113-182

Delgado M, Zuñiga-Feest A, Alvear M, Borie F (2013) The effect of phosphorus on cluster-root formation and functioning of Embothrium coccineum (R. Et J. Forst.). Plant Soil 373:765-773

Delgado M, Suriyagoda L, Zuñiga-Feest A, Borie F, Lambers H (2014) Divergent functioning of Proteaceae species: the south American Embothrium coccineum displays a combination of adaptive traits to survive in high-phosphorus soils. Funct Ecol 28:1356-1366

Dubé F, Stolpe N (2016) SOM and biomass C stocks in degraded and undisturbed Andean and coastal Nothofagus forests of southwestern South America. Forests 7:320-339

Escudey M, Galindo G, Förster JE, Briceño M, Díaz P, Chang A (2001) Chemical forms of phosphorus of volcanic ash-derived soils in Chile. Commun Soil Sci Plant Anal 32:601-616

Etcheverria P, Huygens D, Godoy R, Borie F, Boeckx P (2009) Arbuscular mycorrhizal fungi contribute to $\mathrm{C}-13$ and N-15 enrichment of soil organic matter in forest soils. Soil Biol Biochem 41: $858-861$

George TS, Giles CD, Menezes-Blackburn D, Condron LM, GamaRodrigues AC, Jaisi D, Lang F, Neal AL, Stutter MI, Almeida DS, Bol R, Cabugao KG, Celi L, Cotner JB, Feng G, Goll DS, Hallama M, Krueger J, Plassard C, Rosling A, Darch T, Fraser T, Giesler R, Richardson AE, Tamburini F, Shand CA, Lumsdon DG, Zhang H, Blackwell MSA, Wearing C, Mezeli MM, Almås ÅR, Audette Y, Bertrand I, Beyhaut E, Boitt G, Bradshaw N, Brearley CA, Bruulsema TW, Ciais P, Cozzolino V, Duran PC, Mora ML, de Menezes AB, Dodd RJ, Dunfield K, Engl C, Frazão JJ, Garland G, González Jiménez JL, Graca J, Granger SJ, Harrison AF, Heuck C, Hou EQ, Johnes PJ, Kaiser K, Kjær HA, Klumpp E, Lamb AL, Macintosh KA, Mackay EB, McGrath J, McIntyre C, McLaren T, Mészáros E, Missong A, Mooshammer M, Negrón CP, Nelson LA, Pfahler V, Poblete-Grant P, Randall M, Seguel A, Seth K, Smith AC, Smits MM, Sobarzo JA, Spohn M, Tawaraya K, Tibbett M, Voroney P, Wallander H, Wang L, Wasaki J, Haygarth PM (2018) Organic phosphorus in the terrestrial environments: a perspective on the state of the art and future priorities. Plant Soil 427:191-208

Gerke G (1997) Aluminum and iron (III) species in the soil solution including organic complexes with citrate and humic substances. Z Pflanzenernahr Bodenkd 160:427-432

Gerke J (2010) Humic(organic matter)-Al(Fe)-phosphate complexes: an underestimated phosphate form in soils and source of plant-available phosphate. Soil Sci 175:417-425

Gerke J (2015) Phytate (inositol Hexakisphosphate) in soil and phosphate from inositol phosphates by higher plants. A review. Plants 4:253266

Gilbert GA, Knight JD, Vance CP, Allan DL (1999) Acid phosphatase activity in phosphorus-deficient white lupin roots. Plant Cell Environ 22:801-810

González-Chávez MC, Carrillo-González M, Wright SF, Nichols KA (2004) The role of glomalin, a protein produced by arbuscular mycorrhizal fungi in sequestering potentially toxic elements. Environ Pollut 130:317-323

Gruber BD, Giehl RF, Friedel S, von Wirén N (2013) Plasticity of the Arabidopsis root system under nutrient deficiencies. Plant Physiol 163:161-179 
Hedley H, Steward J, Chauhuan B (1982) Changes in organic and inorganic phosphorus fractions induced by cultivation practices and by laboratory incubations. Soil Sci Soc Am J 46:970-976

Hernández-Soriano MC (2012) The role of aluminum-Organo complexes in soil organic matter dynamics. In: Hernández-Soriano MC (ed) Soil health and land use management. InTech.com Europe, Croatia, pp 17-32

Ho MD, Rosas JC, Brown KM, Lynch JP (2005) Root architectural tradeoffs for water and phosphorus acquisition. Funct Plant Biol 32:737-748

Hong JK, Yamane I (1981) Distribution of inositol phosphate in the molecular size fractions of humic and fulvic acid fractions. Soil Sci Plant Nutr 27:295-303

Irving GCJ, Cosgrove DJ (1982) The use of gas liquid chromatography to determine the proportions of inositol isomers present as pentakisand hexakis-phophates in alkaline extracts of soils. Commun Soil Sci Plant Anal 13:957-967

Liebish L, Keller F, Huguenin-Ellie O, Frossard E, Oberson A, Büneman EK (2014) Seasonal dynamics and turnover of microbial phosphorus in permanent grassland. Biol Fertil Soils 50:465-475

Lynch JP (2007) Roots of the second green revolution. Aust J Bot 55: 493-512

Ma Q, Rengel Z, Rose TJ (2009) The effectiveness of deep placement of fertilisers is determined by crop species and edaphic conditions in Mediterranean-type environments: a review. Aust J Soil Res 47:19 32

Madeira M, Füleky G, Auxtero E (2007) Phosphate sorption of European volcanic soils. In: Bartoli F, Buurman P, Arnalds O, Stoops G, Garcia-Rodeja E (eds) Soils of Volcanic Regions of Europe. Springer, Verlag, pp 353-367

Manske GGB, Ortiz-Monasterio JI, van Ginkel M, González RM, Rajaram S, Molina E, Vlek PLG (2000) Traits associated with improved P-efficiency in CIMMYT's semodwarf spring wheat grown in an acid andisol in Mexico. Plant Soil 221:189-204

Marín C, Aguilera P, Cornejo P, Godoy R, Oehl F, Palfner G, Boy J (2016) Arbuscular mycorrhizal assemblages along contrasting andean forest of southern Chile. J Soil Sci Plant Nutr 16:916-929

Mathew RP, Feng Y, Githinji L, Ankumah R, Balkcom KS (2012) Impact of No-Tillage and Conventional Tillage Systems on Soil Microbial Communities. Appl Environ Soil Sci 2012:548620 10 pages

McLaren TI, Smernik RJ, McLaughlin MJ, McBeath TM, Kirby JK, Simpson RJ et al (2015) Complex forms of soil organic phosphorus- a major component of soil phosphorus. Environ Sci Technol 49:13238-13245

Medina J, Monreal C, Chabot D, Meier S, González ME, Morales E, Parillo R, Borie F, Cornejo P (2017) Microscopic and spectroscopic characterization of humic substances from a compost amended copper contaminated soil: Main features and their potential effects on cu immobilization. Environ Sci Pollut Res 24:14104-14116

Mendoza J, Borie F (1998) The effects of glomus etunicatum inoculation on aluminum, phosphorus, calcium and magnesium uptake in two barley genotypes with different aluminum-tolerance. Commun Soil Sci Plant Anal 9:681-695

Menezes-Blackburn D, Giles C, Darch T, George TS et al (2018) Opportunities for mobilizing recalcitrant phosphorus from agricultural soils: a review. Plant Soil 417:5-26

Mora ML, Canales J (1995) Interactions of humic substances with allophanic compounds. Commun Soil Sci Plant Anal 26:2805-2817

Mora M, Jarvis S, Cartes P (2006) Soil Al availability in Andisols of southern Chile and its effects in forage production and animal metabolism. Soil Use Manag 22:95-101

Morales A, Alvear M, Valenzuela E, Castillo C, Borie F (2011) Screening, evaluation and selection of phosphate-solubilising fungi as potential biofertilizer. J Soil Sci Plant Nutr 11:89-103
Neculman R, Rumpel C, Matus F, Godoy R, Steffens M, Mora ML (2013) Organic matter stabilization in two Andisols of contrasting age under temperate rain forest. Biol Fertil Soils 49:681-689

Nichols KA (2010) Glomalin production and accumulation in soilless pot cultures. Can J Soil Sci 90:567-570

Oehl F, Sieverding PE, Mäder D, Dubois K, Ineichen T, Boller WA (2004) Impact of long-term conventional and organic farming on the diversity of arbuscular mycorrhizal fungi. Oecologia 138:574 583

Oehl F, Laczko E, Bogenrieder A, Stahr K, Bösch R, van der Heijden M, Sieverding E (2010) Soil type and land use intensity determine the composition of arbuscular mycorrhizal fungal communities. Soil Biol Biochem 42:724-738

Pajares N, Gallardo JF, Masciadaro B, Ceccanti B, Etchevers JD (2011) Enzyme activity as an indicator of soil quality changes in degraded cultivated acrisols in the Mexican trans-volcanic belt. Land Degrad Dev 22:373-381

Panichini M, Neculman R, Godoy R, Arancibia-Miranda N, Matus F (2017) Understanding carbon storage in volcanic soils under selectively logged temperate rainforests. Geoderma 302:76-88

Pardo MT, Guadalix ME, García-González MT (1992) Effect of pH and background electrolyte on $\mathrm{P}$ sorption by variable charge soils. Geoderma 54:275-284

Parfitt RL (1989) Phosphate reactions with natural allophane, ferrihydrite and goethite. Eur J Soil Sci 40:359-369

Parfitt RL (2009) Allophane and imogolite: role in soil biochemical processes. Clay Miner 44:135-155

Peirano P, Borie G, Aguilera M (1987) Biochemistry of soils derived from volcanic ashes. V. Determination of polyphenoloxidases. Agric Tecn (Chile) 47:235-239

Pigna M, Violante A (2003) Adsorption of sulphate and phosphate in Andisols. Commun Soil Sci Plant Anal 34:2099-2113

Redel Y, Rubio R, Godoy R, Borie F (2008) Phosphorus fractions and phosphatase activity in an Andisol sampled under different forest ecosystems. Geoderma 145:216-221

Redel Y, Escudey M, Alvear M, Conrad J, Borie F (2011) Effects of tillage and crop rotation on chemical phosphorus and some related biological activities in a Chilean Ultisol. Soil Use Manag 27:221228

Redel Y, Escudey M, Alvear M, Conrad J, Borie F (2015) Effects of land use change on $\mathrm{P}$ bioavailability determined by chemical fractionation and ${ }^{31} \mathrm{P}-\mathrm{NMR}$ spectroscopy in a Nothofagus forest and adjacent grassland. J Soil Sci Plant Nutr 15:1061-1070

Rohyadi A (2005) Spore germination and colonization of Gigaspora margarita as influenced by aluminium concentration. J Microbiol Indones 10:71-74

Rose TJ, Wissuwa M (2012) Rethinking internal phosphorus utilization efficiency. A new approach is needed to improve PUE in grain crops, 1 st edn. Elsevier Inc., Burlington

Rose TS, Rose MT, Tanaka JP, Wissuwa M (2010) Genotypic variation in grain phosphorus concentration, and opportunities to improve P-use efficiency in rice. Field Crop Res 119:154-160

Rubio R, Moraga A, Borie F (1990) Acid phosphatase activity and vesicular mycorrhizal infection associated with roots of four wheat cultivars. J Plant Nutr 13:585-598

Rubio R, Borie F, Schalchli C, Castillo C, Azcón R (2003) Occurrence and effects of arbuscular mycorrhizal propagules in wheat as affected by the source and amount of phosphorus fertilizer and fungal inoculation. Appl Soil Ecol 23:245-255

Rufyikiri G, Declerck C, Dufey JE, Delvaux B (2000) Arbuscular mycorrhizal fungi might alleviate aluminium toxicity in banana plants. New Phytol 148:343-352

Schnitzer MA (2000) Lifetime perspective on the chemistry of soil organic matter. Adv Agron 68:1-58

Seguel A, Medina J, Rubio R, Cornejo P, Borie F (2012) Effects of soil aluminum on early arbuscular mycorrhizal colonization of wheat 
and barley cultivars growing in an Andisol. Chilean J Agric Res 72: 449-455

Seguel A, Cumming J, Klug-Stewart K, Cornejo P, Borie F (2013) The role of arbuscular mycorrhizas in decreasing aluminium phytotoxicity in acidic soils: a review. Mycorrhiza 23:167-183

Seguel A, Barea JM, Cornejo P, Borie F (2015) Role of arbuscular mycorrhizal propagules and glomalin related soil protein in $\mathrm{Al}$ tolerance of two barley cultivars growing in acid soils with hihg Al levels. Crop Pasture Sci 66:696-705

Seguel A, Cumming J, Cornejo P, Borie F (2016) Aluminum tolerance of wheat cultivars in a non-limed and limed Andisol. App Soil Ecol 108:228-237

Seguel A, Cornejo P, Ramos A, von Baer E, Cumming J, Borie F (2017) Phosphorus acquisition by three wheat cultivars contrasting in aluminum tolerance growing in an aluminum-rich Andisol. Crop Pasture Sci 68:315-316

Senesi N, Loffredo E (1992) Soil physical chemistry. In: Sparks D (ed) The chemistry of soil organic matter, 5 th edn. CRC Press

Shoji S, Nanzio M, Dahlgren RA (1993) Volcanic ash soils. Genesis, properties, and utilization. Dev. Soil Sci. 21. Elsevier, Amsterdam

Smith SE, Read AJ (2008) Mycorrhizal symbiosis. Academic Press, London

Takahashi T, Dahlgren RA (2016) Nature, properties and function of aluminum-humus complexes in volcanic soils. Geoderma 263: $110-121$

Torn MS, Trumbore SE, Chadwick OA, Vitousek PM, Hendricks PM (1997) Mineral control of soil organic storage and turnover. Nature 389:170-173

Ugolini FC, Dahlgren RA (2002) Soil development in volcanic ash. Global Environ Res 6:69-82

Valarini PJ, Curaqueo G, Seguel A, Manzano K, Rubio R, Cornejo P, Borie F (2009) Effect of compost application on some properties of a volcanic soil from central South Chile. Chilen J Agric Res 69:416425

van der Heijden MGA, Klironomos JN, Ursic M, Moutoglis P, StreitwolfEngel R, Boller T, Wiemken A, Sanders IR (1998) Mycorrhizal fungal diversity determines plant biodiversity, ecosystem variability and productivity. Nature 396:69-71

Vance CP, Udhe-Stone C, Allan DL (2003) Phosphorus acquisition and use: critical adaptations by plants for securing a nonrenewable resource. New Phytol 157:423-447

Vaneklaas EJ, Lambers H, Bragg J, Finnegan PM, Lovelock CE, Plaxton WC et al (2012) Opportunities for improving phosphorus-use efficiency in crop plants. New Phytol 195:306-320

Velásquez G, Rumpel C, Redel J, Condron LM, Thi Ngo P, CalabiFloody M, Turner B, Mora ML (2016) Chemical nature of residual phosphorus in Andisols. Geoderma 271:27-31

Vistoso E, Theng BKG, Bolan NS, Parfitt RL, Mora ML (2012) Competitive sorption of molybdate and phosphate in Andisols. J Soil Sci Plant Nutr 12:59-72

Wada K (1985) The distinctive properties of andosols. In: Stewart BA (ed) Advances in soil science, vol. 2. Springer, pp 172-229

Wang L, Liao H, Yan X, Zhuang B, Dong Y (2004) Genetic variability for root hair traits as related to phosphorus status in soybean. Plant Soil 261:77-84

Zhang L, Ding X, Peng Y, George TS, Feng G (2018) Closing the loop of phosphorus loss from intensive agricultural soil: a microbial immobilization solution? Front Microbiol 9:104

Zunino H, Borie F, Aguilera M, Martin JP, Haider K (1982a) Decomposition of ${ }^{14} \mathrm{C}$-labeled glucose, plant and microbial products and phenols in volcanic-ash derived soils of Chile. Soil Biol Biochem 14:37-43

Zunino H, Borie F, Aguilera M, Peirano P, Caiozzi M, Martin JP (1982b) Biochemistry of soils derived from volcanic ashes. I. Microbial ecology and its relation with physico-chemical soil properties. Agric Tecn (Chile) 42:67-72

Publisher's Note Springer Nature remains neutral with regard to jurisdictional claims in published maps and institutional affiliations. 